\title{
Analysis of Groundwater on Wetland Area in Kapuas Regency, Central Kalimantan Indonesia
}

\begin{tabular}{l|l|}
\hline Deasy Arisanty & \\
Sidharta Adyatma & (D) \\
Ellyn Normelani $^{3}$ (DD & \\
Apriyanto & \\
&
\end{tabular}

\begin{abstract}
Southern part of Kalimantan is wetland area that included the groundwater basin of PalangkarayaBanjarmasin. The assessment of the potential of ground water in wells includes the quantity of water use on artesian wells, the physical quality of artesian well water and the groundwater uses. The method used in this study is a survey method with the number of wells drilled studied is 17 wells and 46 wells users. Analysis of the data is the percentage obtained from questionnaires distributed to the artesian well. Field measurements obtain the water quality data artesian well. The results showed that the quantity of water is good quantity. The water in wells is never dry despite the dry season. Artesian well water quality is not good for consumption. Based on interviews with residents and the results of field measurements, water color will be red when boiled, so that the water is only used for washing and bathing.
\end{abstract}

Keywords: Groundwater, Wells, Wetlands.

\section{Contents}

1. Introduction

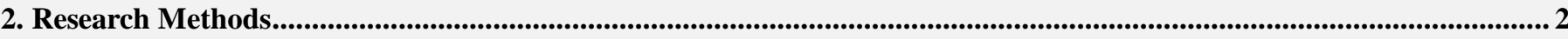

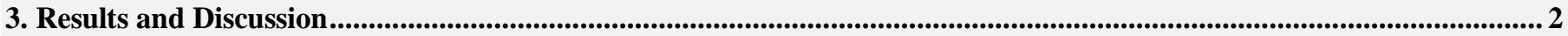

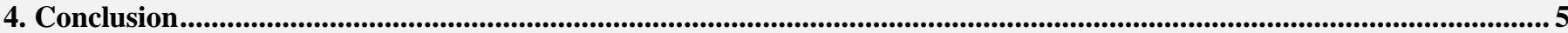

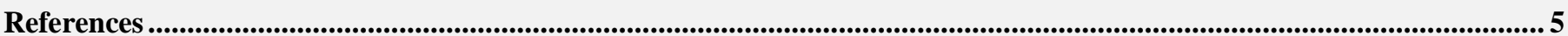

Citation | Deasy Arisanty; Sidharta Adyatma; Ellyn Normelani; Apriyanto (2017). Analysis of Groundwater on Wetland Area in Kapuas Regency, Central Kalimantan Indonesia. Asian Review of Environmental and Earth Sciences, 4(1): 1-6.

DOI:

$\operatorname{ISSN}(\mathbf{E})$

10.20448/journal.506.2017.41.1.6

2313-8173

2518-0134

Licensed: $\quad$ This work is licensed under a Creative Commons Attribution 3.0 License (c)) E

Contribution/Acknowledgement: All authors contributed to the conception and design of the study.

Funding: This study received no specific financial support.

Competing Interests:

The authors declare that they have no conflict of interests.

Transparency: $\quad$ The authors confirm that the manuscript is an honest, accurate, and transparent account of the study was reported; that no

History:

Ethical: vital features of the study have been omitted; and that any discrepancies from the study as planned have been explained.

Publisher:

Received: 31 January 2017/ Revised: 7 March 2017/ Accepted: 9 March 2017/ Published: 10 March 2017

This study follows all ethical practices during writing.

Asian Online Journal Publishing Group 


\section{Introduction}

Development increasing has the effect for the high of water consumers. Water supply source is from surface water, but in some areas, surface water supply is often insufficient. Hence, the other source such as groundwater needs to be inventoried [1].

Potential of groundwater always refers to the quantity of the groundwater availability and quality of groundwater [2]. Good quantity and good quality of groundwater is used for community needs. Community needs consists of domestic uses, i.e. for drinking and non-domestic uses, i.e. for agriculture. The domestic and non-domestic uses have impact for water quantity and quality [3].

Wetland is the high of potential waters but the human intervention may have effect for the waters quantity and quality. The decreases of wetland area may decreases amount of waters in wetland areas $[4,5]$. The effect of human activity for water in wetland area are high urbanization, high population, mining and oil activity, industrial activity, illegal logging, overgrazing, transportation, uncontrolled agricultural, uncontrolled land reclamation. The natural effects for wetland area are subsidence, saltwater intrusion, sand storm, desertification and droughts, invasion of alien flora and fauna [5].

Kuala Kapuas Regency is part of groundwater basin of Banjarmasin-Palangkaraya. The basin is wetland area. The spread of the water basin covers an area of $\pm 95,980 \mathrm{~km}^{2}$. The major aquifer lithology of basin is alluvium sediment beaches, rivers and wetlands such as gravel, gravel, and sand with graduation medium-high, and less coherent sedimentary rock composed of quartz sandstones and conglomerates, with high graduation. Precipitation in the basin has ranges between 2,000-2,500 mm/year. Groundwater potential in the shallow aquifer (non-distressed) is about $\pm 32,393 \times 10 \mathrm{~m}^{3} /$ year [6].

Potential groundwater in the basin is very high. Groundwater resources can be utilized as a source of clean water in groundwater basin of Banjarmasin-Palangkaraya. The higher of population growth in the region, the higher also need water for daily use [6].

The objectives of research are to analyze the quantity of groundwater in artesian well of Kapuas Regency, to analyze the quality of groundwater in artesian well of Kapuas Regency, to analyze groundwater uses in Kapuas Regency.

\section{Research Methods}

The research location is wetland area in groundwater basin of Banjarmasin-Palangkaraya. Groundwater is taken through artesian well, which the artesian well are spread throughout the basin. The number of samples is 17 of wellbore. Respondents from user of artesian well are 43 people. Data are obtained through a questionnaire to identify the quantity of groundwater (the amount of ground water in the artesian well, the material, the depth of the wells, drought artesian well, material in the artesian well, the quality of drilled wells, and the type of use of the artesian well). Field measurements collects the physical quality of groundwater which includes the taste of water, the color of water, the smell of the water, temperature, electrical conductivity (EC), the content of $\mathrm{NaCl}$, and TDS. The location of research is presented in Figure 1.
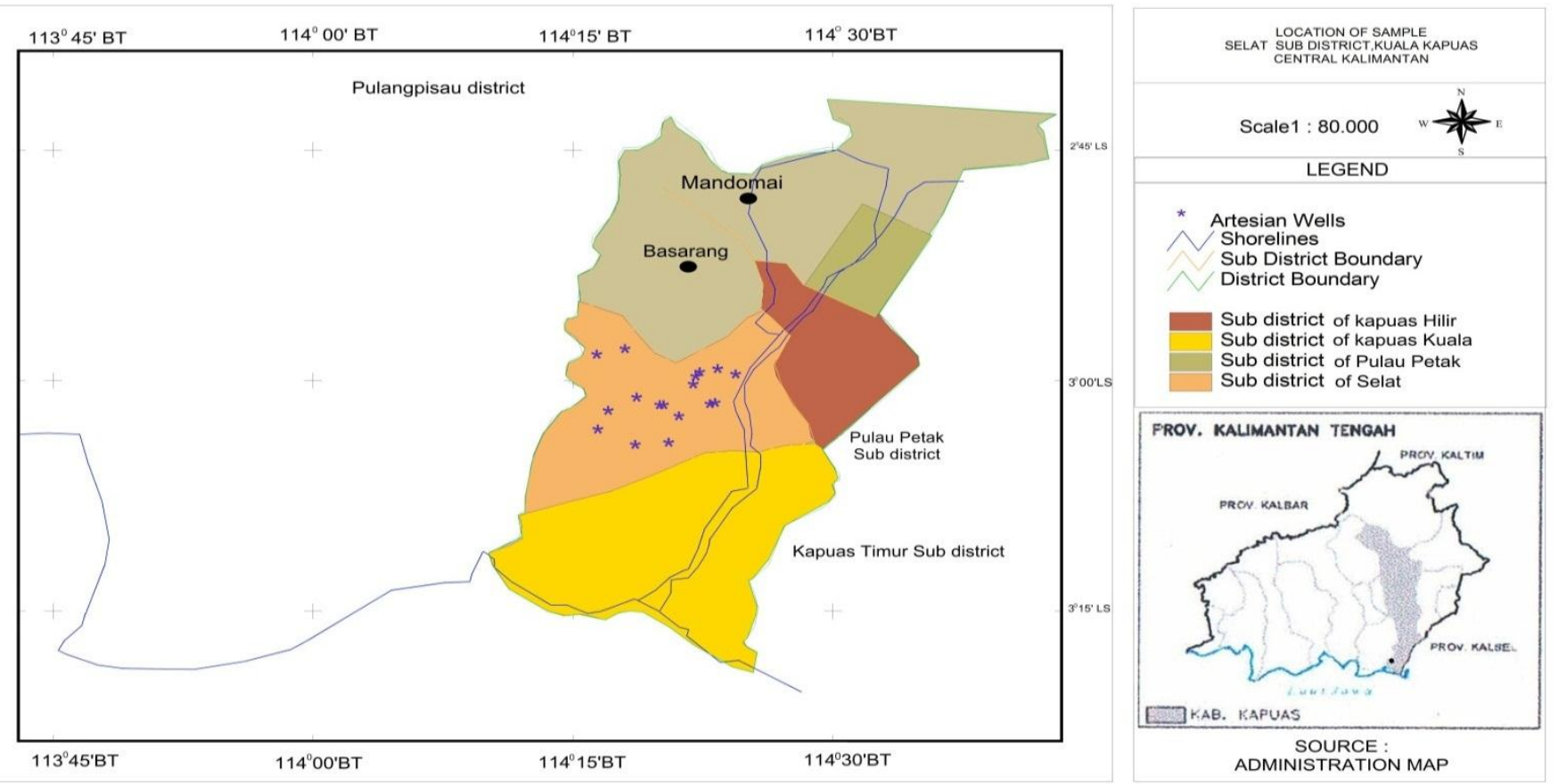

Source: Administration map of Kapuas District (2016)

Figure-1. Location of research

\section{Results and Discussion}

A. Potential of Groundwater in Artesian well in Research Area

1. Quantity of Groundwater

a. The Quantity of Ground Water in the Artesian Well

The quantity of groundwater is determined by the amount of available of groundwater during the wet season and dry season. More of water taken in the artesian well indicates that groundwater has large quantities. Groundwater in artesian wells in the wet season and dry season is presented in Table 1 and Figure 1. 
Table-1. The quantity of groundwater uses in wet season and dry season

\begin{tabular}{l|l|l|l|l}
\hline \multirow{2}{*}{ Criteria } & \multicolumn{2}{|c|}{ Wet season } & \multicolumn{2}{c}{ Dry season } \\
\cline { 2 - 5 } & $\mathbf{F}$ & $\mathbf{\%}$ & $\mathbf{f}$ & \% \\
\hline 40-60 liter & 40 & 93.02 & 4 & 9.30 \\
\hline 60-80 liter & 1 & 2.33 & 3 & 6.98 \\
\hline 80-100 liter & 2 & 4.65 & 2 & 4.65 \\
\hline$>100$ liter & 0 & 0.00 & 34 & 79.07 \\
\hline Total & $\mathbf{4 3}$ & $\mathbf{1 0 0}$ & $\mathbf{4 3}$ & $\mathbf{1 0 0}$ \\
\hline
\end{tabular}

Source: Primary data analysis (2016)

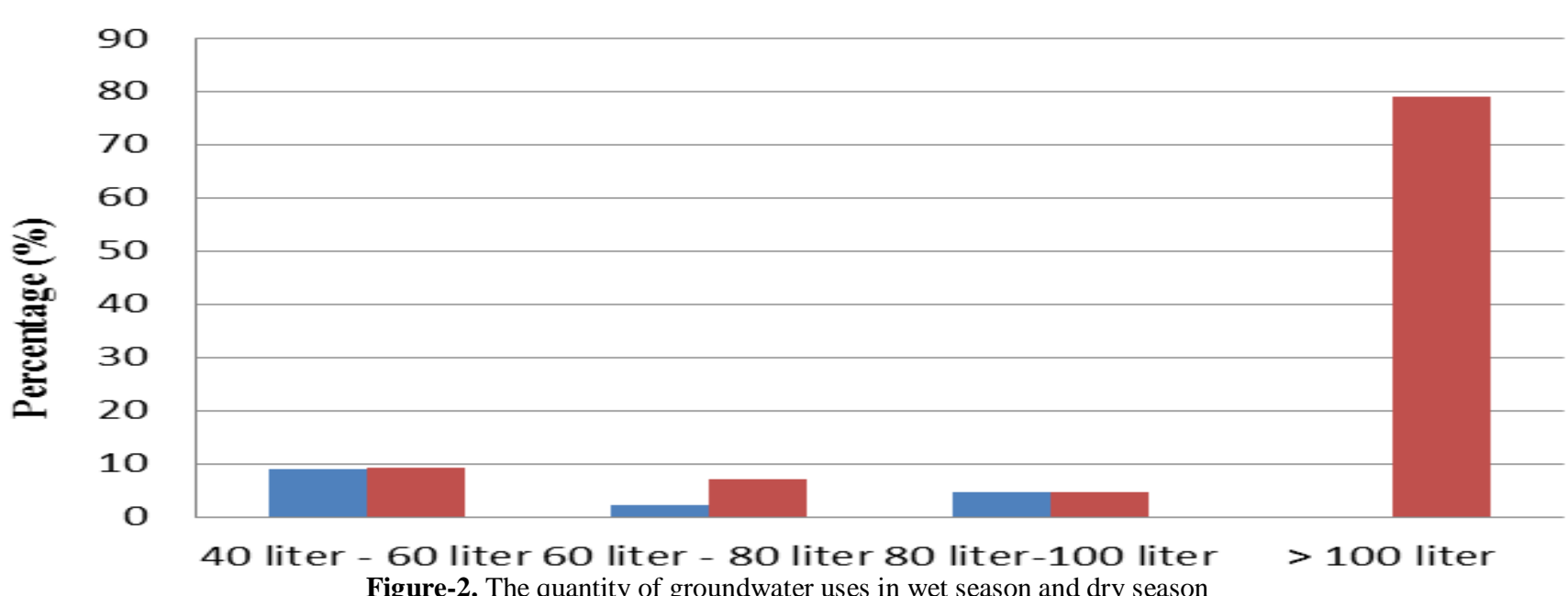

Source: Primary Data Analysis (2016)

igure-2. The quantity of groundwater uses in wet season and dry season

Artesian well is used by the people, especially in the dry season due to people use water from other sources in wet season, example from rainwater and rivers. Water wells uses approximately $79.07 \%$ of people. This indicates that the water wells have a good potential to serve as a source of clean water for daily needs, especially in the dry season.

\section{b. The Depth of the Artesian Well}

Artesian well in swamp area is a relatively deep well to obtain the high groundwater quantity and good quality. The depth of wells drilled in the study area is presented in Table 2 and Figure 2.

Table-2. The depth of the artesian well

\begin{tabular}{|c|c|c|}
\hline Criteria & Frequency (f) & Percentage (\%) \\
\hline$<50$ meter & 2 & 4.65 \\
\hline $50-75$ meter & 1 & 2.33 \\
\hline $75-100$ meter & 5 & 11.63 \\
\hline$>100$ meter & 35 & 81.40 \\
\hline Total & 43 & 100 \\
\hline
\end{tabular}

Wells in the study area is a deep well, since $81.4 \%$ has a depth of $>100$ meters. It is intended to get water in large quantities and a better quality. The Shallow wells have a risk of drought and low of ph.

\section{c. Drought in Artesian Wells}

Drought in artesian well may occur in the dry season. Drought of artesian well is presented in Table 3.

Table-3. The Artesian Wells Drought

\begin{tabular}{|c|c|c|}
\hline Criteria & Frequency (f) & Percentage $(\%)$ \\
\hline Never & 40 & 93.02 \\
\hline Sometimes & 2 & 4.65 \\
\hline Often & 1 & 2.33 \\
\hline Always & 0 & 0.00 \\
\hline Total & 43 & 100 \\
\hline
\end{tabular}

The data in Table 3 indicates that drought never occurred in wells. About $93.02 \%$ of the respondents claimed that drought never occurs in the rainy season and the dry season. This indicates that the wells in the wetland of Kapuas Regency has good potential due to water is always available in the wet season and the dry season.

\section{d. Materials of Groundwater}

Material of well determine the quantity of groundwater. Groundwater with the sand material has the good aquifer. Material on the wells is presented in Table 4. 
Table-4. Material of wells artesian

\begin{tabular}{l|l|l}
\multicolumn{3}{c}{ Table-4. Material of wells artesian } \\
\hline Criteria & Frequency (f) & Percentage (\%) \\
\hline Sand and gravel & 10 & 23.26 \\
\hline Fine sand & 32 & 74.42 \\
\hline Clay & 1 & 2.33 \\
\hline Rock & 0 & 0.00 \\
\hline Total & $\mathbf{4 3}$ & $\mathbf{1 0 0 . 0 0}$ \\
\hline Source: Primary data analysis (2016) &
\end{tabular}

The data in Table 4 illustrates that the material in the wells is dominated by fine sand $(74.42 \%)$. Sand and gravel has the percentage about $23.26 \%$.The groundwater in the study area included in the aquifer. It means the groundwater has a good potential. There are approximately $2.33 \%$ of wells has a clay material. This means that the wells artesian have the low potential. The wellbore is possible to dry, especially during the dry season.

\section{Groundwater Quality}

Result of ground water measurement is presented in Table 5.

Table-5. Groundwater quality

\begin{tabular}{l|l|l|l|l|l|l|l|l|l}
\hline No & Sub district & Village & $\begin{array}{l}\text { Water } \\
\text { flavor }\end{array}$ & $\begin{array}{l}\text { Temperature } \\
\left({ }^{\mathbf{0}} \mathbf{C}\right)\end{array}$ & $\begin{array}{l}\text { DHL } \\
(\boldsymbol{\mu s})\end{array}$ & $\begin{array}{l}\text { NaCl } \\
(\boldsymbol{\%})\end{array}$ & $\begin{array}{l}\text { TDS } \\
\mathbf{p p m}\end{array}$ & Color & Water Smell \\
\hline 1 & Selat & Selat Dalam & tasteless & 29.4 & 578 & 1.50 & 287 & Clear & Smell of mud \\
\hline 2 & Selat & Selat Dalam & tasteless & 29.4 & 577 & 1.50 & 286 & Clear & Smell of mud \\
\hline 3 & Selat & Selat Dalam & tasteless & 29.4 & 578 & 1.50 & 287 & Clear & Smell of mud \\
\hline 4 & Selat & Selat Dalam & tasteless & 29.3 & 578 & 1.50 & 287 & Clear & Smell of mud \\
\hline 5 & Selat & Selat Dalam & tasteless & 29.4 & 578 & 1.50 & 286 & Clear & Smell of mud \\
\hline 6 & Selat & Selat Dalam & tasteless & 29.3 & 577 & 1.50 & 286 & Clear & Smell of mud \\
\hline 7 & Selat & Selat Utara & tasteless & 31.8 & 349 & 1.10 & 174 & Clear & odorless \\
\hline 8 & Selat & Selat Utara & tasteless & 31.3 & 350 & 1.20 & 173 & Clear & odorless \\
\hline 9 & Selat & Selat Utara & tasteless & 31.7 & 350 & 1.10 & 173 & Clear & odorless \\
\hline 10 & Selat & Selat Utara & tasteless & 31.8 & 348 & 1.10 & 174 & Clear & odorless \\
\hline 11 & Selat & Selat Tengah & tasteless & 31.6 & 752 & 1.90 & 375 & Clear & odorless \\
\hline 12 & Selat & Selat Barat & tasteless & 31.6 & 536 & 1.40 & 262 & Clear & odorless \\
\hline 13 & Selat & Selat Hilir & tasteless & 30 & 561 & 1.40 & 279 & Clear & odorless \\
\hline 14 & Selat & Selat Hilir & tasteless & 30 & 560 & 1.40 & 278 & Clear & odorless \\
\hline 15 & Selat & Selat Hilir & tasteless & 30.5 & 560 & 1.40 & 278 & Clear & odorless \\
\hline 16 & Selat & Selat Hilir & tasteless & 30.2 & 753 & 1.90 & 376 & Clear & odorless \\
\hline 17 & Selat & Selat Barat & tasteless & 31.7 & & & & Clear & odorless \\
\hline
\end{tabular}

Source: Primary data analysis (2016)

Table 5 illustrates the quality of artesian well water of about 17 boreholes have been measured physical quality. In terms of taste, water wellbore has the tasteless with the temperatures ranging between $31.8-29.3{ }^{\circ} \mathrm{C}$. Electrical conductivity is low, it means that the water is fresh water due to the DHL value is an approximately 300-500 $\mu$ s. $\mathrm{NaCl}$ content is about $1.2-1.9 \% \mathrm{NaCl}$ or low of $\mathrm{NaCl}$. TDS value or the amount of sediment dissolved is ranging from 100-300 ppm, which means including a lower category. Wellbore water is also in clear conditions but some of the wellbore has mud smell. In general, wellbore waters in the study area in terms of the physical qualities are eligible to be used for everyday purposes.

Table-6. Physical quality of ground water in the wellbore based on user perception

\begin{tabular}{l|l|l|l|l|l|l}
\hline \multirow{2}{*}{ Criteria } & Water smell & Water color & \multicolumn{2}{l}{ Water turbidity } \\
\cline { 2 - 7 } & Frequency (f) & Percentage (\%) & Frequency (f) & Percentage (\%) & Frequency (f) & Percentage (\%) \\
\hline Never & 23 & 53.49 & 36 & 83.72 & 36 & 83.72 \\
\hline Rarely & 16 & 37.21 & 5 & 11.63 & 4 & 9.30 \\
\hline Often & 2 & 4.65 & 2 & 4.65 & 2 & 4.65 \\
\hline Always & 2 & 4.65 & 0 & 0.00 & 1 & 2.33 \\
\hline Total & $\mathbf{4 3}$ & $\mathbf{1 0 0}$ & $\mathbf{4 3}$ & $\mathbf{1 0 0}$ & $\mathbf{4 3}$ & $\mathbf{1 0 0}$ \\
\hline
\end{tabular}

Source: Primary data analysis (2016)

Based on the analysis in Table 6 most users stated that the wellbore are never odorless, colorless, and not cloudy. Thus, the people stated that in terms of physical quality, wellbore water in research area is classified as good of physical quality.

\section{B. The Uses of Groundwater}

The use of groundwater in wellbore in research area is presented in Table 7.

Based on data in Table 7 the most of the water in the wellbore is used for household needs such as for drinking, sanitation, bathing and washing. This is consistent with the objective of making the wellbore to satisfy the needs of clean water in the wetland area. The non-domestic uses of wells waters are for mosque and schools.

Table 8 explains that the most people do not use artesian well water for drinking and cooking. According to them, if the water is heated, the water color will change to red indicating the iron content in the water is high enough. This causes people to worry poisoning when consumed the water from an artesian well. The water is used for sanitation, bathing, and washing. Thus, although the potential is high artesian well water but the water cannot be used for drinking water sources. People still have to look for other water sources, for example from rainwater or bottled 
water factory with a better quality than the water in the wellbore. Nevertheless, the presence of artesian well water helps the community to meet the needs of water for sanitation, bathing and washing, especially during the dry season.

Table-7. The use of groundwater in the wellbore

\begin{tabular}{l|l|l|l}
\hline No & Sub District & Village & Groundwater uses \\
\hline 1 & Selat & Selat Dalam & Domestic \\
\hline 2 & Selat & Selat Dalam & Domestic \\
\hline 3 & Selat & Selat Dalam & Domestic \\
\hline 4 & Selat & Selat Dalam & Domestic \\
\hline 5 & Selat & Selat Dalam & Domestic \\
\hline 6 & Selat & Selat Dalam & Domestic \\
\hline 8 & Selat & Selat Utara & Domestic \\
\hline 9 & Selat & Selat Utara & Domestic \\
\hline 10 & Selat & Selat Utara & Non domestic \\
\hline 11 & Selat & Selat Utara & Non domestic \\
\hline 12 & Selat & Selat Tengah & Domestic \\
\hline 13 & Selat & Selat Barat & Domestic \\
\hline 14 & Selat & Selat Hilir & Domestic \\
\hline 15 & Selat & Selat Hilir & Domestic \\
\hline 16 & Selat & Selat Hilir & Domestic \\
\hline 17 & Selat & Selat Barat & Domestic \\
\hline Source: Primary data analysis $(2016)$ & &
\end{tabular}

Source: Primary data analysis (2016)

Tabel-8. Groundwater uses

\begin{tabular}{|c|c|c|c|c|c|c|c|c|c|c|}
\hline \multirow{2}{*}{ Criteria } & \multicolumn{2}{|c|}{ Drinking } & \multicolumn{2}{|c|}{ Cooking } & \multicolumn{2}{|c|}{ Sanitation } & \multicolumn{2}{|c|}{ Bathing } & \multicolumn{2}{|c|}{ Washing } \\
\hline & f & $\%$ & f & $\%$ & $\mathbf{f}$ & $\%$ & $\mathbf{f}$ & $\%$ & $\mathbf{f}$ & $\%$ \\
\hline Always & 0 & 0.00 & 1 & 2.33 & 12 & 27.91 & 23 & 53.49 & 24 & 55.81 \\
\hline Often & 1 & 2.33 & 3 & 6.98 & 22 & 51.16 & 14 & 32.56 & 19 & 44.19 \\
\hline Rarely & 3 & 6.98 & 4 & 9.30 & 6 & 13.95 & 2 & 4.65 & 0 & 0.00 \\
\hline Never & 39 & 90.70 & 35 & 81.40 & 3 & 6.98 & 4 & 9.30 & 0 & 0.00 \\
\hline Total & 43 & 100 & 43 & 100 & 43 & 100 & 43 & 100 & 43 & 100 \\
\hline
\end{tabular}

Groundwater contained in wetland area of Banjarmasin Palangkaraya have high potential due to the wells is never drought despite in the dry season. Water is also categorized as a good aquifer because of the sand material. People use the groundwater in large quantities, especially in the dry season. Wellbore has been the source of water used by the public, especially in the dry season. Physical quality of groundwater in research area is tasteless, colorless, tasteless, low salt content, and low sediment dissolved which indicates that the physical quality of water is good.

Groundwater is contained in the wellbore has been used by people for their daily needs, especially for sanitation, washing and bathing. People do not use artesian well water for cooking or drinking because the water will be changed to red when heated. Community use rainwater or bottled water for drinking and cooking.

Wetland groundwater has the high of dissolved organic carbon due to the groundwater flows through the high of organic sediment [7]. The flood flows through groundwater has effect for characteristic of groundwater and surface water on wetland [8]. Surface water flows in wetland, then groundwater rises stagnant [9].

Arisanty [10] stated that the basin of Banjarmasin-Palangkaraya, especially in Barito Delta has the material consist of sand, clay, and sand and brackish water. Sand layer has the thickness about $7 \mathrm{~m}$, clay has the thickness about 36-65 m sand and brackish water has the thickness about $29 \mathrm{~m}$. The thickness of sand material indicates that the basin has the high potential of groundwater but the organic material and brackish water decreases the quality of groundwater.

\section{Conclusion}

The quantity of groundwater in wellbore is good because the wells never drought despite in the dry season. Generally, physical quality of water wells is good quality, but there are few boreholes smelling mud that indicates a less good quality. Wellbore water is used for sanitation, bathing and washing. Water is not used for drinking and cooking because of their reddish color when water is heated.

\section{References}

[1] M. J. Erwinta, W. Matondang, W. Sumartiani, and H. Simanjuntak, "Hydrogeological mapping scale of 1: 50,000 in Kapuas, Central Kalimantan Province," Research Report, Ministry of Mines and Energy of the Central Kalimantan Province, Bandung, 1996.

[2] R. S. Hidayat, "Groundwater potential of groundwater Basin in Sambas, Kalimantan Barat Province," Jurnal Geologi Indonesia, vol. 3, pp. 205-212, 2008.

[3] S. Singh, N. J. Raju, and C. Ramakrishna, "Evaluation of groundwater quality and its suitability for domestic and irrigation use in parts of the Chandauli-Varanasi Region,Uttar Pradesh, India," Journal of Water Resource and Protection, vol. 7, pp. 482-497, 2015. View at Google Scholar | View at Publisher

[4] K. P. Nyarugwe, "Effect of surface water management measures on a groundwater fed Wetland," Thesis, The Faculty of GeoInformation Science and Earth Observation of the University of Twente, 2016.

[5] H. O. Nwankwoala, "Case studies on coastal Wetlands and water resources in Nigeria," European Journal of Sustainable Development, vol. 1, pp. 113-126, 2012. View at Google Scholar

[6] Sihwanto and Wahyudin, "Groundwater conservation of Palangkaraya-Banjarmasin Basin and Pagatan Basin, South Kalimantan Basin Pagatan," Research Report, Ministry of Mines and Energy of the Central Kalimantan Province, Bandung, 2005. 
[7] J. F. Elder, N. B. Rybicki, V. Carter, and V. Weintraub, "Sources and yields of dissolved carbon in Northern Wisconsin Stream catchments with differing amounts of Peatland," Wetlands, vol. 20, pp. 113-125, 2000. View at Google Scholar IView at Publisher

T. S. McCarthy, "Groundwater in the wetlands of the Okavango Delta, Botswana, and its contribution to the structure and function of the ecosystem," Journal of Hydrology, vol. 320, pp. 264-282, 2006. View at Google Scholar $\mid$ View at Publisher

[9] P. Schot and T. Winter, "Groundwater-surface water interactions in Wetlands for integrated water resources management," Preface, Journal of Hydrology, vol. 320, pp. 261-263, 2006. View at Google Scholar $\mid$ View at Publisher

[10] Arisanty, Morphodynamic of Barito Delta, Southern Kalimantan. Dissertation, faculty of geography. Yogyakarta, Indonesia: Gadjah Mada University, 2013. 